\title{
RANCANG BANGUN PINTU WAHANA OTOMATIS MENGGUNAKAN SENSOR ULTRASONIK HC-SR04 SEBAGAI PENGUKUR TINGGI BADAN DAN SENSOR LOAD CELL DENGAN HX711 SEBAGAI PENGUKUR BERAT BADAN BERBASIS ARDUINO MEGA 2560
}

\author{
Agung Hanifan Lutfiyanto, Arkhan Subari \\ Program Studi Diploma III Teknik Elektro \\ Sekolah Vokasi, Universitas Diponegoro
}

\begin{abstract}
Agung Hanifan Lutfiyanto, Arkhan Subari, in this paper explain that at present, profit plyaground still uses manual measurement to select visitors who will enter the vehicle. Measuring just selecting one's height by putting aside weight can have a negative impact on the smoothness and safety of the playing area. Therefore, an automation is needed to measure body weight and height to be safer from game accidents and increase vehicle life to avoid damage. This design makes the device an automatic vehicle area entrance system using Arduino Mega 2560 for the main controller system supported by various sensors namely HC-SR04 ultrasonic sensor as a measure of prospective visitor height, $100 \mathrm{Kg}$ Load Cell sensor as a measure of prospective visitor's weight and motor servo as the opening and closing door of the vehicle. When prospective visitors will enter the vehicle, prospective visitors stand on their height and weight gauges. Furthermore, Arduino compares with the standard height and weight previously set. If the weight and height are in accordance with the standard, the door will open automatically and visitors can enter the vehicle. For testing the prospective visitor's height as measured by the HC-SR04 ultrasonic sensor has an average error ratio of $1.01 \%$, while testing prospective visitor's weight measured by sensor Load Cell has an average error ratio of $2.90 \%$ and is calculated quite accurate.
\end{abstract}

Keywords: Automatic door, Arduino Mega 2560, HC-SR04 Ultrasonic sensor, Load Cell sensor, Servo Motor

\section{PENDAHULUAN}

Pada masa modern ini, banyak sekali ditemukan wahana - wahana permainan yang beraneka macam jenisnya, ada yang indoor atau di dalam ruangan dan ada juga yang outdoor atau di luar ruangan/lapangan terbuka. Semua jenis wahana - wahana permainan tersebut memiliki kapasitasnya masing - masing agar mesin wahana - wahana permainan tersebut dapat bekerja dengan maksimal. Salah satu kapasitas yang diukur dalam suatu wahana permainan yang besar adalah persoalan tentang pemakainya atau manusianya, yaitu tentang tinggi dan berat badan pengunjungnya.

Tinggi dan berat badan seseorang mempengaruhi dari kinerja wahana permainan khususnya untuk wahana permainan outdoor dan berpengaruh juga kepada keselamatan manusianya itu sendiri. Sekarang masih banyak dijumpai, penggunaan berat dan tinggi badan penggunanya diabaikan yang berakibat terjadinya kecelakaan pada wahana tersebut. Ada juga yang sudah menyeleksi pengunjung wahana tersebut dengan mengukur berat dan tinggi badan pengunjungnya, namun itu semua masih menggunakan metode manual manual dan juga tersedia yang otomatisasi namun hanya mengukur tinggi badan pengunjung saja

Dari permasalahan tersebut mendorong penyusun untuk membuat sebuah terobosan alat yang dapat digunakan untuk mengontrol dan memonitoring pengunjung yang masuk pada suatu area wahana permainan tertentu. Judul yang penyusun ajukan yaitu "Rancang Bangun Pintu
Wahana Otomatis Menggunakan Sensor Ultrasonik HC-SR04 Sebagai Pengukur Tinggi Badan Dan Sensor Load Cell Dengan Hx711 Sebagai Pengukur Berat Badan Berbasis Arduino".

\section{Sensor Ultrasonik HC-SR04}

Sensor ultrasonik adalah sebuah sensor yang berfungsi untuk mengubah besaran fisis (bunyi) menjadi besaran listrik dan sebaliknya ${ }^{[1]}$. Cara kerja sensor ini didasarkan pada prinsip dari pantulan suatu gelombang suara sehingga dapat dipakai untuk menafsirkan eksistensi (jarak) suatu benda dengan frekuensi tertentu. Disebut sebagai sensor ultrasonik karena sensor ini menggunakan gelombang ultrasonik (bunyi ultrasonik).

Gelombang ultrasonik adalah gelombang bunyi yang mempunyai frekuensi sangat tinggi yaitu $20.000 \mathrm{~Hz}^{[1]}$. Bunyi ultrasonik tidak dapat di dengar oleh telinga manusia. Bunyi ultrasonik dapat didengar oleh anjing, kucing, kelelawar, dan lumbalumba. Bunyi ultrasonik bisa merambat melalui zat padat, cair dan gas. Reflektivitas bunyi ultrasonik di permukaan zat padat hampir sama dengan reflektivitas bunyi ultrasonik di permukaan zat cair. Akan tetapi, gelombang bunyi ultrasonik akan diserap oleh tekstil dan busa. Gambar 1 menunjukkan bentuk fisik sensor ultrasonic. 


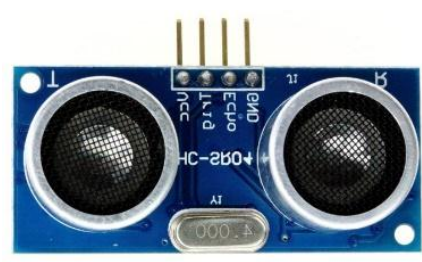

Gambar 1. Sensor Ultrasonik HC-SR04

\section{Sensor Load Cell 100Kg}

Load Cell adalah sebuah alat uji perangkat listrik yang dapat mengubah suatu energi menjadi energi lainnya yang biasa digunakan untuk mengubah suatu gaya menjadi sinyal listrik ${ }^{[2]}$.

Sensor Load Cell merupakan sensor yang dirancang untuk mendeteksi tekanan atau berat sebuah beban ${ }^{[2]}$, sensor Load Cell umumnya digunakan sebagai komponen utama pada sistem timbangan digital dan dapat diaplikasikan pada jembatan timbangan yang berfungsi untuk menimbang berat dari truk pengangkut bahan baku, pengukuran yang dilakukan oleh Load Cell menggunakan prinsip tekanan. Gambar 2 memperlihatkan tampilan dari sensor load cell.

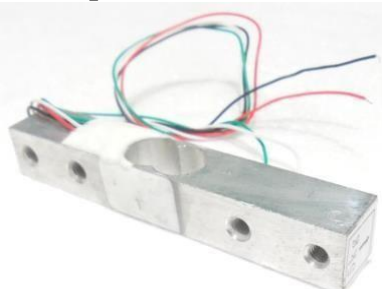

Gambar 2. Sensor Load Cell

\section{ADC HX711}

HX711 adalah sebuah komponen modul presisi 24-bit analog to digital conventer (ADC) yang didesain untuk sensor timbangan digital dan industrial control aplikasi yang terkoneksi sensor jembatan ${ }^{[4]}$.

HX711 adalah modul timbangan, yang memiliki prinsip kerja mengkonversi perubahan yang terukur dalam perubahan resistansi dan mengkonversinya ke dalam besaran tegangan melalui rangkaian yang ada[4]. Modul melakukan komunikasi dengan computer/mikrokontroler melalui TTL232. Struktur yang sederhana, mudah dalam penggunaan, hasil yang stabil dan reliable, memiliki sensitivitas tinggi, dan mampu mengukur perubahan dengan cepat. Pada gambar 2.12 digambarkan tentang diagram blok kerja dari modul ADC HX711 terhadap sensor Load Cell. Gambar 3. Merupakan diagram blok dari ADC HX711

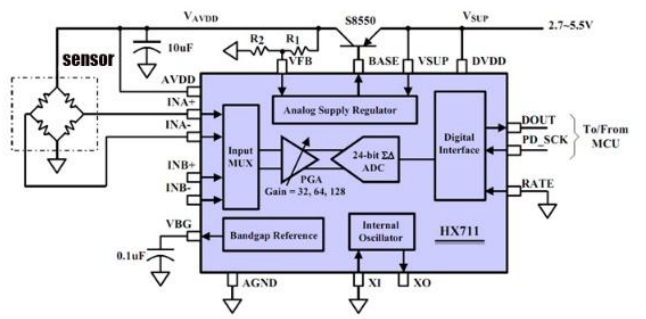

Gambar 3. Blok Diagram HX711

\section{CARA KERJA SISTEM KESELURUHAN}

Gambar 4 menunjukkan diagram blok sistem yang akan dibuat sedangkan gambar 5 memperlihatkan gambar rangkaian keseluruhan.

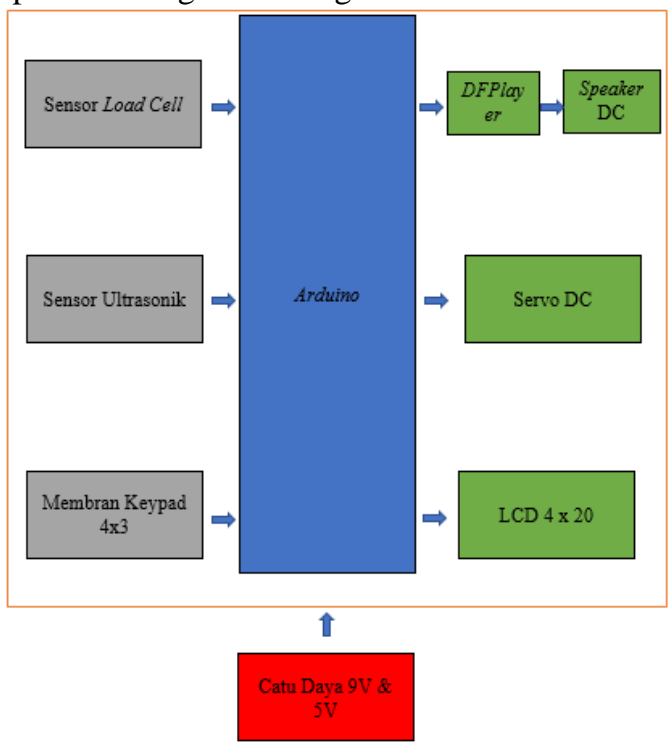

Gambar 4. Rangkaian Diagram Blok Keseluruhan Dari Sistem Rangkaian

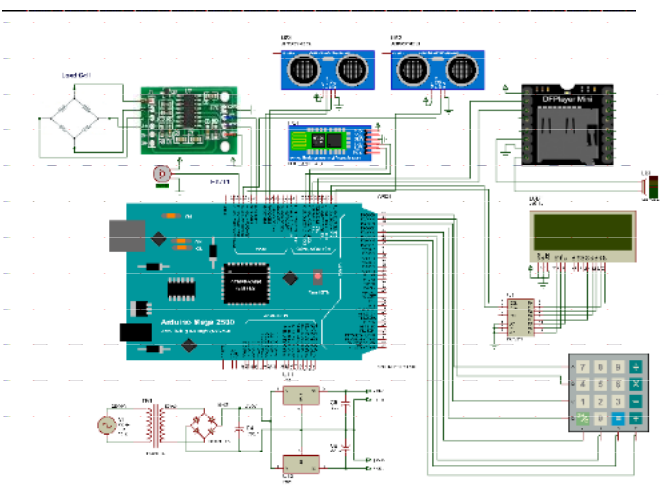

Gambar 5. Rangkaian keseluruhan 


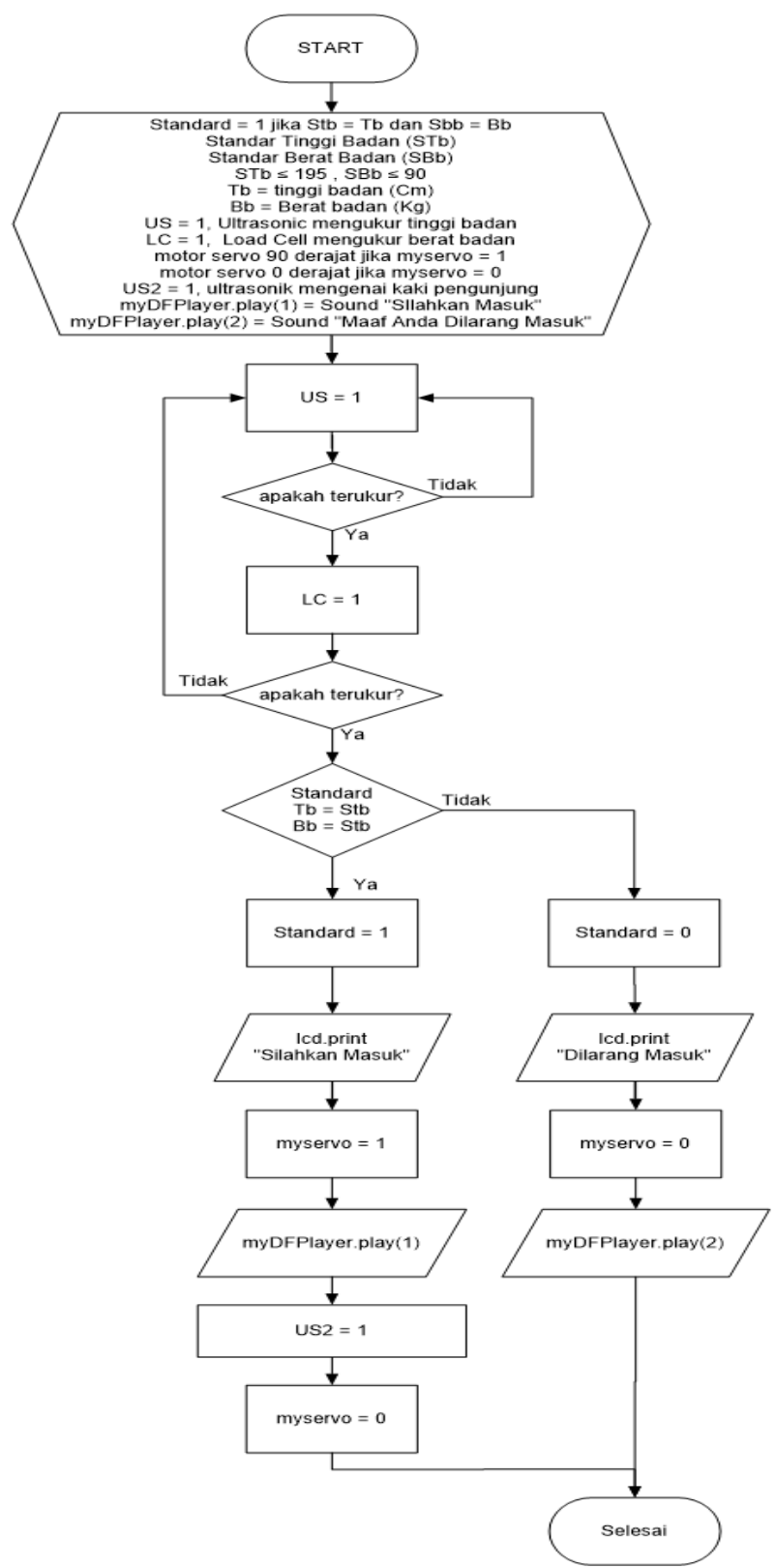

Gambar 6. Flowchart Keseluruhan

Gambar 6 memperlihatkan flowchart sistem secara keseluruhan. Dalam sebuah sistem, masing masing perangkat telah memiliki identitasnya masing - masing dan port - port perangkat yang berbeda, yang menghubungkan antara perangkat dan mikroprosesornya. Disini penyusun menggunakan mikroprosesor Arduino Mega 2560 yang memiliki input output 54 buah (15 I/O PWM) yang sangat mendukung banyaknya sensor atau perangkat lainnya yang penyusun inginkan. Pertama, sebelum pengunjung memasuki suatu wahana permaianan, pengunjung akan diukur tinggi dan berat badannya oleh sensor Ultrasonik dan sensor Load Cell. Saat pengunjung naik ke timbangan Load Cell, diatas kepalanya telah ada sensor ultrasonik yang siap untuk mengukur tinggi badan pengunjung dan sensor Load Cell yang mengukur berat badan pengunjung tersebut. Jika tinggi dan berat badan pengunjung masuk kriteria yang diperbolehkan masuk ke dalam wahana permainan, maka akan muncul suara "Silahkan Masuk" yang merupakan output dari speaker DC yang diberi inputan perintah dari DFplayer dan gerbang akan terbuka otomatis. Sebaliknya, jika pengunjung wahana tidak masuk kriteria dari pengunjung yang boleh memasuki suatu wahana, maka speaker akan berbunyi "Dilarang Masuk" dan gerbang tidak terbuka. Saat pengunjung melewati gerbang, maka pengunjung akan terkena sensor ultrasonik yang berfungsi sebagai tanda untuk menutup gate yang terbuka tadi. Jika ingin mengganti standar dari berat badan dan tinggi badan pengunjung yang boleh masuk, maka petugas bisa mengaturnya menggunakan keypad yang ada pada kotak kontrol.

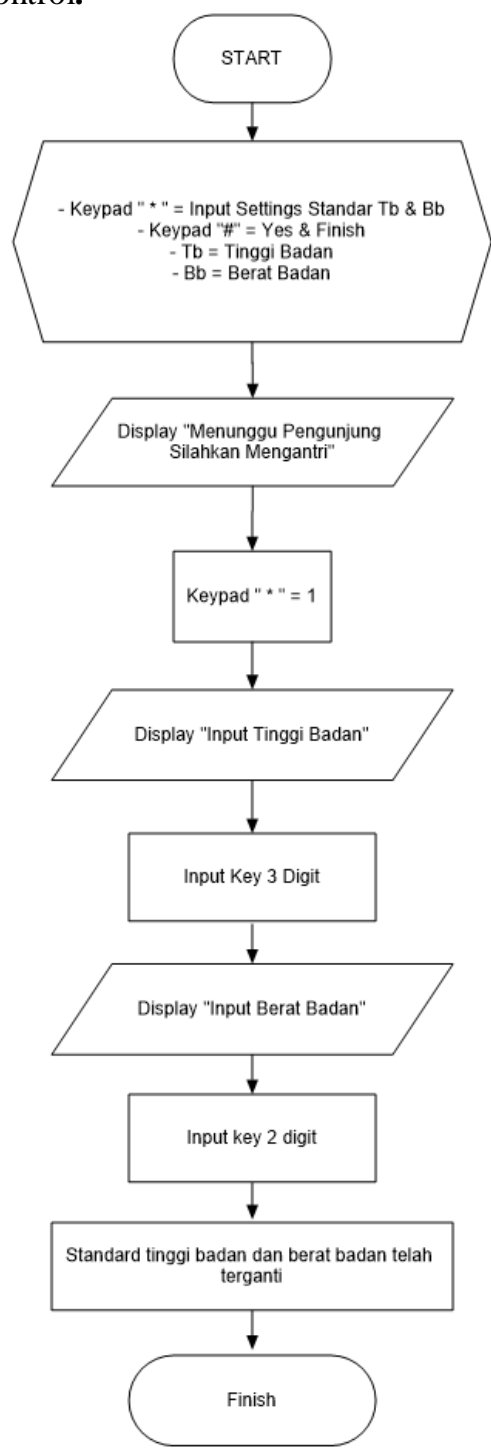

Gambar 7. Flowchart Setting Tinggi dan Berat Badan

Diagram alur setting tinggi dan berat badan pengunjung diperlihatkan pada gambar 7. Pertama, Arduino Mega 2560 akan akan bekerja setelah system On Karena mendapatkan supplai sebesar 5 Volt tegangan DC dari Catu daya. Lalu, Display 
LCD akan bertuliskan "Menunggu Pengunjung Silahkan Mengantri" yang berarti jika kita ingin mengatur standar tinggi dan berat badan pengunjung wahana yang masuk, maka tekan tombol * pada keypad. Setelah Keypad * ditekan, maka layer LCD akan muncul tulisan "Input Tinggi Badan". Selanjutnya masukan 3 digit karakter angka yang akan diatur sebagai standar tinggi badan, misal kita inputkan di keypad " 150 ” yang berarti standar tinggi badan untuk pengunjung yang memasuki wahana harus minimal atau sama dengan $150 \mathrm{~cm}$ dan maksimal setinggi $195 \mathrm{~cm}$. Selanjutnya tekan tombol \# lalu display LCD akan bertuliskan "input Berat Badan" yang berarti memasukkan 2 digit karakter angka yang diatur sebagai standar berat badan, misal kita inputkan di keypad "50" yang berarti standar berat badan untuk pengunjung yang memasuki wahana harus minimal atau sama dengan $50 \mathrm{~kg}$ dan maksimal $90 \mathrm{~kg}$. Setelah itu tekan tombol \# ,semua pengaturan telah selesai. Ini menandakan standar yang tadi diperbaharui akan tersimpan untuk proses seleksi pengunjung yang memasuki wahana selanjutnya.

\section{PENGUJIAN DAN ANALISIS}

Pengukuran dan pengujian dilakukan pada masing-masing rangkaian. Hal itu bertujuan untuk mendeteksi kemungkinan adanya kesalahan pada rangkaian. Selain itu juga untuk mengetahui nilai besaran listrik keluarannya. Titik-titik pengukuran catu daya ditunjukkan pada gambar 8 .

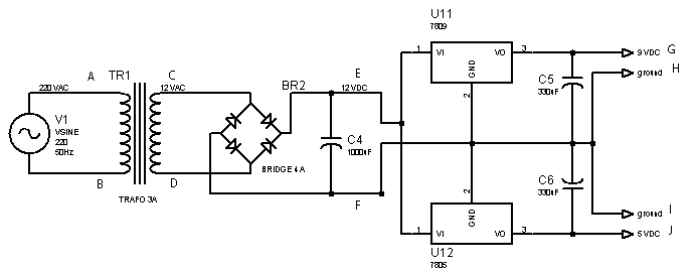

Gambar 8. Pengukuran Rangkaian Catu Daya

Pengukuran rangkaian catu daya pada dasarnya bertujuan untuk mengetahui tegangan keluaran akhir dari rangkaian catu daya agar tegangan keluaran dapat stabil guna mensupply masing-masing modul. Pada sistem ini menggunakan rangkaian catu daya 5 Volt dan 9 Volt. Pengukuran rangkaian catu daya dilakukan menggunakan voltmeter untuk mengetahui tegangan output. Hasil pengukuran catu daya ditampilkan pada tabel 1 .
Tabel 1. Data hasil Pengukuran Rangkaian Catu

\begin{tabular}{clll} 
Daya & & & \\
\hline No & $\begin{array}{l}\text { Bagian } \\
\text { yang } \\
\text { diukur }\end{array}$ & $\begin{array}{l}\text { Titik } \\
\text { Pengukuran }\end{array}$ & Tegangan (V) \\
\hline 1 & $\begin{array}{l}\text { Input } \\
\text { Trafo }\end{array}$ & A-B & 225.6 \\
2 & $\begin{array}{l}\text { Output } \\
\text { Trafo }\end{array}$ & C-D & 12.5 \\
3 & $\begin{array}{l}\text { Output } \\
\text { diode } \\
\text { bridge } \\
\text { Output }\end{array}$ & E-F & 15.6 \\
4 & $\begin{array}{l}\text { IC 7809 } \\
\text { Output }\end{array}$ & I-J & 9.18 \\
IC 7805 & & 5 \\
\hline & & &
\end{tabular}

Pengujian pada sensor ultrasonik dilakukan untuk mengamati bagaimana penyimpangan dan selisih yang dilakukan sensor ultrasonik dalam beberapa kali pengukuran. Hasilnya ditunjukkan pada tabel 2 .

Tabel 2. Data Hasil pengujian Sensor Ultrasonik

\begin{tabular}{lllll}
\hline No & $\begin{array}{l}\text { Pembacaan } \\
\text { Sensor }(\mathbf{P}) \\
\text { cm }\end{array}$ & $\begin{array}{l}\text { Pengukuran } \\
\text { Meteran } \\
(\mathbf{Q}) \mathbf{c m}\end{array}$ & $\begin{array}{l}\text { Selisih } \\
\mathbf{c m}\end{array}$ & $\begin{array}{l}\text { Rasio } \\
\text { Kesalahan } \\
\text { \% }\end{array}$ \\
\hline 1 & 171 & 170 & 1 & 0.58 \\
2 & 173 & 171 & 2 & 1.15 \\
3 & 165 & 164 & 1 & 0.6 \\
4 & 164 & 162 & 2 & 1.21 \\
5 & 166 & 163 & 3 & 1.8 \\
6 & 163 & 162 & 1 & 0.61 \\
7 & 168 & 167 & 1 & 0.59 \\
8 & 166 & 164 & 2 & 1.2 \\
9 & 170 & 168 & 2 & 1.17 \\
10 & 164 & 162 & 2 & 1.21 \\
\multicolumn{4}{l}{ Rata-rata rasio kesalahan \% } \\
\hline
\end{tabular}

Pengujian pada sensor Load Cell dilakukan untuk mengamati dan mengetahui berat badan calon pengunjung, seperti pada tabel 3 .

Tabel 3. Data Hasil pengujian Sensor Load Cell

\begin{tabular}{lllll}
\hline No & $\begin{array}{l}\text { Pembacaan } \\
\text { Sensor (P) } \\
\text { kg }\end{array}$ & $\begin{array}{l}\text { Pengukuran } \\
\text { timbangan } \\
\text { analog (Q) } \\
\text { kg }\end{array}$ & $\begin{array}{l}\text { Selisih } \\
\text { kg }\end{array}$ & $\begin{array}{l}\text { Rasio } \\
\text { Kesalahan } \\
\%\end{array}$ \\
\hline 1 & 61 & 60 & 1 & 1.63 \\
2 & 64 & 63 & 2 & 1.56 \\
3 & 45 & 43 & 2 & 4.44 \\
4 & 43 & 41 & 2 & 4.65 \\
5 & 46 & 45 & 1 & 2.17 \\
6 & 43 & 42 & 1 & 2.32 \\
7 & 47 & 45 & 2 & 4.25 \\
8 & 51 & 50 & 1 & 1.96 \\
9 & 53 & 51 & 2 & 3.77 \\
10 & 44 & 43 & 1 & 2.27 \\
\hline \multicolumn{4}{l}{ Rata-rata rasio kesalahan \% } \\
\hline
\end{tabular}


Pengujian Sistem ini dilakukan untuk menghitung dan mengetahu berapa tingkat kepekaan sistem yang telah di buat yang hasilnya ditunjukkan pada tabel 4 .

Tabel 4. Data Hasil Pengujian Sistem Seleksi Pintu Wahana

\begin{tabular}{|c|c|c|c|c|c|c|}
\hline \multirow[t]{2}{*}{ No } & \multicolumn{2}{|c|}{$\begin{array}{l}\text { Pembacaan } \\
\text { Sensor (P) kg }\end{array}$} & \multicolumn{2}{|c|}{$\begin{array}{l}\text { Pengukuran } \\
\text { timbangan } \\
\text { analog }(Q) \mathrm{kg}\end{array}$} & \multirow{2}{*}{$\begin{array}{l}\text { Posisi } \\
\text { Motor } \\
\text { Servo } \\
\left(0^{0} / 9^{0}\right)\end{array}$} & \multirow[t]{2}{*}{$\begin{array}{l}\text { Lolos } \\
\text { /Tdk } \\
\text { Lolos }\end{array}$} \\
\hline & $\begin{array}{l}\text { Tinggi } \\
\mathrm{cm}\end{array}$ & $\begin{array}{l}\text { Berat } \\
\mathrm{kg}\end{array}$ & $\begin{array}{l}\text { Tinggi } \\
\mathrm{cm}\end{array}$ & $\begin{array}{l}\text { Berat } \\
\mathrm{kg}\end{array}$ & & \\
\hline 1 & 160 & 40 & 171 & 61 & $90^{\circ}$ & Lolos \\
\hline 2 & 160 & 40 & 158 & 41 & $0^{0}$ & $\begin{array}{l}\text { Tdk } \\
\text { lolos }\end{array}$ \\
\hline 3 & 160 & 40 & 165 & 15 & $90^{\circ}$ & Lolos \\
\hline 4 & 160 & 40 & 164 & 43 & $90^{\circ}$ & Lolos \\
\hline 5 & 160 & 40 & 166 & 46 & $90^{\circ}$ & Lolos \\
\hline 6 & 170 & 50 & 170 & 51 & $90^{\circ}$ & Lolos \\
\hline 7 & 170 & 50 & 169 & 59 & $0^{0}$ & $\begin{array}{l}\text { Tdk } \\
\text { lolos }\end{array}$ \\
\hline 8 & 170 & 50 & 173 & 64 & $90^{\circ}$ & Lolos \\
\hline 9 & 170 & 50 & 169 & 47 & $0^{0}$ & $\begin{array}{l}\text { Tdk } \\
\text { lolos }\end{array}$ \\
\hline 10 & 170 & 50 & 167 & 47 & $0^{0}$ & $\begin{array}{l}\text { Tdk } \\
\text { lolos }\end{array}$ \\
\hline
\end{tabular}

\section{KESIMPULAN}

Kesimpulan yang diperoleh adalah sebagai berikut :

- Hasil pengujian pengukuran tinggi badan menggunakan sensor ultrasonik HC-SR04 mampu diaplikasikan pada sistem pengukuran tinggi badan karena rata-rata error yang didapatkan maksimal sebesar $1,01 \%$ masih pada batas toleransi dan cukup akurat.

- Hasil pengujian pengukuran berat badan menunjukkan bahwa antara sensor yang menunjukkan berat badan mampu diaplikasikan pada sistem pengukuran berat badan karena ratarata error yang didapatkan maksimal sebesar 2,90 $\%$ masih pada batas toleransi dan cukup akurat.

- Hasil pengujian standar tinggi dan berat badan dengan tinggi dan berat badan calon pengunjung dapat berjalan dengan baik dan cukup akurat dengan presentasi keberhasilan seleksi sebesar $100 \%$ dan tingkat eror sebesar $0 \%$.

\section{DAFTAR PUSTAKA}

1. Muhammad Khoiruddin , Afif. 2015. Pengembangan Alat Ukur Tinggi Badan Dan Berat Badan Digital Yang Terintegrasi (Skripsi). Yogyakarta: Universitas Negeri Yogyakarta.

2. Aditya Rahmat Abdillah dan Tartilla Alib Zamzami. 2013. Sistem Buka Dan Tutup Pintu Wahana Safari Otomatis Menggunakan Kamera Untuk Mencegah Binatang Keluar. Surabaya: Institut Teknologi Sepuluh Nopember.
3. Santoso, Hari. 2015. Cara Kerja Sensor Ultrasonik, Rangkaian, \& Aplikasinya. http://www.elangsakti.com/2015/05/sensor ultrasonik.html diakses pada Senin, 2 Mei 2017.

4. Al-Mutlaq, Sarah. 2003. Getting Started with Load Cells. https://learn.sparkfun.com/tutorials/gettingstarted-with-load-cells diakses pada tanggal 6 Oktober 2017.

5. Semiconductor, AVIA. 24-Bit Analog-toDigital Converter (ADC) for Weigh Scales. Datasheet. China: AVIA.

6. Elisa. 2017. Bab X Motor Servo 10.1 Pendahuluan. Yogyakarta: Universitas Gajah Mada.

7. Anonim. FeeTech FS5109M - Metal Gear Servo.

https://servodatabase.com/servo/feetech/fs5109

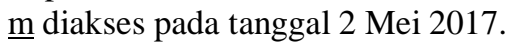

8. Anonim. 2015. Mengenal Arduino Mega 2560. http://ecadio.com/belajar-dan mengenalArduino-mega diakses pada tanggal 2 Mei 2017.

9. Ardianto, Dani. 2016. Membuat Project dengan Arduino dengan Arduino dan modul DFPlayer mini (Serial mp3 Player). http://www.belajArduino.com/2016/10/Arduino p.html diakses pada tanggal 2 Mei 2017. 